\title{
MEMBANGUN POLITIK KRIMINAL PADA PERTAMBANGAN BATUBARA YANG MENYEJAHTERAKAN MASYARAKAT MELALUI SARANA NON-PENAL
}

\section{Build Politics Criminal in the Coal Mining to Welfare of Public through Means of Non-Penal}

\section{Arif Firmansyah}

Euis D. Suhardiman

Fakultas Hukum, Universitas Islam Bandung

email:arifunisba05@gmail.com

\begin{abstract}
In Article 33 paragraph (3) of the Constitution of 1945, states earth water and natural resources contained therein controlled by the state and used for the welfare of the people. The realization of such mastery by delegating the authority to manage the natural resources of the state to the company is to provide state Mining Permit or Special Mining Permit. In protecting and overseeing the company that is engaged in coal mining government passed Law Number 4 of 2009 on Mineral and Coal Mining. In Article 162 of Law Number 4 of 2009 states that every person who impede or interfere mining activities from business license holders of mining and business permit of the mining specifically penalized by fines or imprisonment. The article shows a process of criminalization an action (criminal policy), which aim to protect the companies that already have a Mining Permit, but the criminal policy is contrary to the purpose of the criminal policy is an effort for the welfare of society and policies the protection of society, the existence of Article 162 of Law Minerals coal and coal mining communities can impede convicted. In the case of the counteraction form caused they want to protect the environment or their ancestral lands from exploration activities. So it is activity is not uncommon form of criminal policy by means of criminal law that gives rise to new conflicts. Therefore the criminal policy should be shifted from penal facilities to non-penal policy more accommodating community participation, so that the purpose of the criminal policy, namely the welfare of society and protect the community can be realized.
\end{abstract}

Keywords: Political Criminal, Mining, Non-Penal 


\section{abstrak}

Dalam Pasal 33 ayat (3) UUD 1945 menyebutkan bumi air dan kekayaan alam yang terkandung didalamnya dikuasai oleh negara dan dipergunakan untuk sebesar-besarnya kemakmuran rakyat. Wujud dari penguasaan tersebut dengan pendelegasian wewenang pengelolaan sumber daya alam dari negara kepada perusahaan adalah dengan cara negara memberikan Izin Usaha Pertambangan atau Ijin Usaha Pertambangan Khusus. Dalam melindungi dan mengawasi perusahaan yang bergerak dalam bidang pertambangan batu bara pemerintah mengeluarkan Undang-Undang Nomor 4 Tahun 2009 tentang Pertambangan Mineral dan Batubara. Dalam Pasal 162 UU Nomor 4 tahun 2009 yang menyebutkan bahwa setiap orang yang merintangi atau mengganggu kegiatan usaha pertambangan dari pemegang izin usaha pertambangan dan izin usaha pertambangan khusus dikenakan sanksi denda atau hukuman penjara. Pasal tersebut menunjukkan suatu proses pengriminalisasian suatu tindakan (kebijakan kriminal) yang tujuannya melindungi perusahaan yang telah memunyai Izin Usaha Pertambangan, akan tetapi kebijakan kriminal tersebut bertentangan dengan tujuan dari kebijakan kriminal yaitu upaya untuk menyejahterakan masyarakat dan kebijakan perlindungan masyarakat, dengan adanya Pasal 162 UU tentang Mineral dan Batubara masyarakat yang merintangi pertambangan batubara dapat dipidana. Pada hal bentuk perintangan tersebut disebabkan karena mereka ingin melindungi lingkungan atau tanah adatnya dari kegiatan eksplorasi. Sehingga tidak jarang bentuk kebijakan kriminal melalui sarana hukum pidana tersebut menimbulkan konflik-konflik baru. Untuk itu maka kebijakan kriminalnya harus bergeser dari sarana penal ke kebijakan Non-penal yang lebih mengakomodir partisipasi masyarakat, sehingga tujuan dari kebijakan kriminal yaitu menyejahterakan masyarakat dan melindungi masyarakat dapat terwujud.

\section{Kata Kunci: Politik Kriminal, Pertambangan, Non-Penal}

\section{A. Pendahuluan}

Dalam Pasal $33^{1}$ ayat (3) Undang-Undang Dasar Negara Republik Indonesia 1945 menegaskan bahwa "bumi, air dan kekayaan alam dikuasai oleh negara dan dipergunakan sebesar-besar untuk kemakmuran rakyat".

\footnotetext{
${ }^{1}$ Dalam perkembangannya, setelah amandemen Undang-Undang Dasar 1945 keempat pada tanggal 10 Agustus 2002, Pasal ini ditambah dengan memasukkan 2 (dua) ayat baru, yaitu: Pasal 33 UUD 1945 ayat (4) perekonomian Indonesia diselenggarakan berdasar atas demokrasi ekonomi dengan prinsip kebersamaan, efisiensi berkeadilan, berkelanjutan, berwawasan lingkungan, kemandirian, serta dengan menjaga keseimbangan kemajuan dan kesatuan ekonomi nasional. Ayat (5) ketentuan lebih lanjut mengenai pelaksanaan pasal ini diatur oleh undang-undang.
} 
Kata-kata dikuasai oleh negara secara etimologis adalah dikuasai oleh negara (kalimat Pasif) memunyai padanan arti menguasai negara atau penguasaan negara (kalimat aktif). Pengertian kata "menguasai" ialah berkuasa atas (sesuatu), memegang kekuasaan atas (sesuatu), sedangkan pengertian kata "penguasaan" berarti proses, cara, perbuatan, menguasai atau mengusahakan. ${ }^{2}$

Menurut putusan Mahkamah Konstitusi hak menguasai negara bukan dalam makna negara memiliki, tetapi dalam pengertian bahwa negara hanya merumuskan kebijakan (beleid), melakukan pengaturan (regelendaad), melakukan pengurusan (besturdaad), melakukan pengelolaan (beheerdaad), dan melakukan pengawasan (toezichthoundendaad). ${ }^{3}$ Mengingat mineral dan batubara sebagai kekayaan alam yang terkandung di dalam bumi merupakan sumber daya alam yang tidak dapat diperbaharui, maka pengelolaannya perlu dilakukan secara optimal, efisien, transparan, berkelanjutan dan berwawasan lingkungan, serta berkeadilan agar memperoleh manfaat sebesar-besar bagi kemakmuran rakyat secara berkelanjutan. ${ }^{4}$

Dalam kerangka penguasan negara atas pertambangan mengandung pengertian negara memegang kekuasan untuk menguasai dan mengusahakan segenap sumber daya bahan galian yang terdapat dalam wilayah hukum pertambangan Indonesia. Penguasaan dan pemanfaatan sumber daya alam sebagaimana ditegaskan dalam (Pasal 33 ayat (3) UUD 1945) tersebut adalah dalam rangka hak penguasaan negara, tidak berarti dikelola atau diusahakan oleh negara atau pemerintah dengan birokrasinya, tetapi dapat menyerahkan kepada usaha swasta, asalkan tetap di bawah penguasaan negara atau pemerintah. ${ }^{5}$ Wujud penyerahan kepada swasta adalah kepada perusahaan negara atau BUMN. ${ }^{6}$ Perusahaan pertambangan negara yang mengusahakan bahan galian yang strategis dan diberikan kewenangan penuh untuk melakukan usahanya termasuk melakukan hubungan dengan pihak ketiga, asalkan segala kemajuan dan hasil produksinya tetap di bawah pengendalian serta pengawasan negara. ${ }^{7}$

2 Kamus Besar Bahasa Indonesia, (edisi kedua), (Jakarta: Departemen Pendidikan dan Kebudayaan \& Balai Pustaka, 1995), hlm. 533.

${ }^{3}$ Pan Mohamad Faiz, Penafsiran Konsep Penguasaan Negara Berdasarkan Pasal 33 UUD 1945 dan Putusan Mahkamah Konstitusi, www. Jurnal Hukum. Blogspot.com, diakses 24 November 2010.

${ }^{4}$ Lihat Pasal 4 Undang-Undang Nomor 4 Tahun 2009 tentang Pertambangan Mineral dan Batu Bara.

${ }^{5}$ Mohammad Hatta, Ekonomi Terpimpin, (Jakarta: Djambatan, 1967), hlm. 46.

${ }^{6}$ Misalnya perusahaan Minyak dan Gas Bumi oleh Pertamina dan PT. Gas Negara, Listrik oleh PT. PLN dan berbagai Public Utilities lainnya.

${ }^{7}$ H. Abrar Saleng, Hukum Pertambangan, Cet 2, (Yogyakarta: UII Press, 2004), hlm. 31. 
Terkait dengan fungsi negara Friedman menegaskan adanya empat fungsi negara dalam bidang ekonomi yaitu pertama, fungsi negara sebagai provider (penjamin) kesejahteraan masyarakat; kedua fungsi negara sebagai regulator (pengatur); ketiga, fungsi negara sebagai entrepreunerur (Pengusaha) atau menjalankan sektor tertentu melalui state owned corporation (BUMN); keempat, fungsi negara sebagai umpire (pengawasan, wasit) untuk merumuskan standar yang adil mengenai kinerja sektor ekonomi termasuk perusahaan negara (state corporation). ${ }^{8}$

Secara ketatanegaraan bentuk keterlibatan negara dalam pengelolaan sumber daya mineral dan batubara ada 3 yakni pengaturan (regulasi), pengusahaan mengurus dan pengawasan. Aspek pengaturan merupakan hak mutlak negara yang tidak boleh diserahkan kepada swasta dan merupakan aspek yang paling utama diperankan negara di antara aspek lainnya. Penguasaan dalam bidang pertambangan batubara tidak semuanya dapat dilakukan oleh negara, maka pengusahaan (hak pengusahaan) dapat dilimpahkan kepada badan hukum swasta atau perorangan dalam wilayah hukum pertambangan Indonesia dengan izin usaha pertambangan atau izin usaha pertambangan khusus. ${ }^{9}$

Izin usaha pertambangan bukan suatu mekanisme pengalihan hak negara, tetapi sarana atau instrumen yang memungkinkan pihak swasta dapat berpartisipasi dalam usaha pertambangan. ${ }^{10}$ Selain dari aspek pengusahaan negara yang bisa diserahkan kepada swasta lewat izin usaha pertambangan, negara (pemerintah) juga memunyai fungsi keterlibatan di dalam menjamin usaha pertambangan tersebut bisa berjalan dengan aman, tertib, dan damai.

Dalam menjalankan fungsinya negara sebagai penjamin, negara mengaplikasikannya dalam bentuk peraturan perundang-undangan. Dalam menjamin usaha pertambangan tersebut supaya lancar pemerintah mengeluarkan Undang-Undang Nomor 4 tahun 2009 tentang Pertambangan Mineral dan Batubara, dalam peraturan tersebut memuat mengenai pemberian izin usaha pertambangan kepada pihak swasta, ${ }^{11}$ untuk memperoleh izin usaha pertambangan tersebut pemerintah menentukan syarat-syarat yang harus dipenuhi oleh perusahaan pertambangan batubara. Apabila syarat-syarat telah dipenuhi maka pemerintah mengeluarkan izin usaha pertambangan. Setelah perusahaan batubara mendapatkan izin usaha pertambangan, maka negara wajib menjamin keberlangsungan perusahaan untuk melaksanakan kegiatan pertambangan batubara.

Bentuk jaminan atau perlindungan tersebut tertuang dalam Pasal 162 Undang-Undang Nomor 4 Tahun 2009 tentang Pertambangan Mineral dan

\footnotetext{
${ }^{8}$ Ibid, hlm. 16

${ }^{9}$ Andrian Sutendi, Hukum Pertambangan, Cet 1, (Jakarta: Sinar Garfika, 2011), hlm. 25.

${ }^{10} \mathrm{Ibid}$.

${ }^{11}$ Lihat Pasal 35 UU No. 4 Tahun 2009 tentang Pertambangan Mineral dan Batubara.
} 
batubara yang menyebutkan bahwa setiap orang yang merintangi atau mengganggu kegiatan usaha pertambangan dari pemegang izin usaha pertambangan dan izin usaha pertambangan khusus dikenakan sanksi denda atau hukuman penjara. Jadi setiap orang yang merintangi pertambangan maka dikenakan sanksi pidana. Bentuk penerapan sanksi tersebut sebagai usaha untuk menanggulangi kejahatan di bidang pertambangan batubara. Pasal 162 Undang-Undang Nomor 4 Tahun 2009 tentang Pertambangan Mineral dan batubara bertujuan untuk melindungi pemegang izin supaya aman melaksanakan kegiatannya. Dengan adanya sanksi pidana tersebut negara berusaha untuk membuat peraturan hukum yang tujuan untuk menanggulangi kejahatan di bidang pertambangan. Dimuatnya ketentuan tersebut merupakan kebijakan kriminal negara yang tadinya perbuatan merintangi tersebut bukan merupakan suatu tindak pidana menjadi suatu tindak pidana. Kebijakan kriminal merupakan "suatu usaha yang rasional dari masyarakat dalam menanggulangi kejahatan". Kebijakan atau upaya penanggulangan kejahatan pada hakikatnya merupakan bagian integral dari upaya perlindungan masyarakat (social defence) dan upaya mencapai kesejahteraan masyarakat (social welfare). Tujuan dari politik kriminal adalah "perlindungan masyarakat untuk mencapai kesejahteraan masyarakat". ${ }^{12}$.

Dalam realitanya Pasal 162 Undang-Undang Nomor 4 Tahun 2009 tentang Pertambangan Mineral dan batubara menjadi sarana kekerasan yang dilakukan oleh negara yang kontradiksi dengan tujuan dari penerapan pidana tersebut. Walhi mencatat, sepanjang 2010, setidaknya 28 orang mendekam di tahanan. Sebanyak 37 orang lain berurusan dengan pihak Kepolisian karena berjuang untuk kelestarian ruang hidup dari penetrasi tambang. ${ }^{13}$ Penerapan penanganan masalah hukum di bidang pertambangan dengan sarana penal tersebut menimbulkan konflik-konflik baru. Untuk itu maka kebijakan kriminalnya harus bergeser dari kebijakan penal kebijakan Nonpenal yang lebih mengakomodir partisipasi masyarakat, sehingga tujuan dari kebijakan kriminal yaitu menyejahterakan masyarakat dan melindungi masyarakat dapat terwujud. Dalam tulisan ini akan dikaji tentang membangun politik kriminal pada pertambangan batubara yang menyejahterakan masyarakat melalui sarana non-penal.

Metode Penelitian yang digunakan adalah yuridis normatif yaitu penelitian hukum yang mempergunakan sumber data sekunder, ${ }^{14}$ dengan menyusun kerangka konsepsional, dengan merumuskan ketentuan yang

12 Barda Nawawi Arief, Kebijakan Hukum Pidana Perkembangan Penyususnan Konsep KUHP Baru, (Jakarta: Kencana, 2008), hlm. 1.

${ }^{13}$ Hukumonline, unsur pemidanaan di UU minerba, diakses tanggal 21 Februari 2013

${ }^{14}$ Ronny Hanitijo Soemitro, Metodologi Penelitian Hukum dan Jurimetri, cet ke-4(Jakarta: Galia Indonesia , 1990), hlm. 115. 
terdapat dalam Peraturan Perundang-undangan yang menjadi dasar penelitian. ${ }^{15}$ Penelitian yuridis normatif terhadap asas-asas hukum bertolak dari premis-premis yang berupa norma positif yaitu Undang-Undang Nomor Undang-Undang Nomor 4 Tahun 2009 tentang Pertambangan.

Penulisan penelitian ini dilakukan dengan menggunakan pendekatan undang-undang (statute approach) dan pendekatan konseptual. Penelitian normatif tidak dapat melepaskan diri dari pendekatan perundang-undangan karena yang akan diteliti adalah berbagai aturan hukum yang menjadi fokus sekaligus tema sentral suatu penelitian sehingga suatu penelitian normatif pasti akan menggunakan pendekatan perundang-undangan walaupun penelitian tersebut mengarahkan pada kekosongan hukum. ${ }^{16}$ Pendekatan perundang-undangan digunakan berkenaan dengan peraturan hukum yang mengatur tentang Pertambangan Mineral dan batu bara (Undang-Undang Nomor 4 Tahun 2009). Pendekatan konseptual (conceptual approach) jika kita kaji pengertian Konseptual, berasal dari kata konsep yang berarti unsurunsur abstrak yang mewakili kelas-kelas fenomena dalam suatu bidang studi yang kadangkala menunjuk pada hal-hal yang partikular. Salah satu fungsi konsep adalah memunculkan, objek-objek yang menarik perhatian dari sudut pandangan praktis dan sudut pengetahuan dalam pikiran dan atribut-atribut tertentu. ${ }^{17}$ Kemudian pendekatan konseptual digunakan berkenaan dengan konsep-konsep mengenai kebijakan kriminal.

\section{B. Pembahasan}

\section{Membangun Politik Kriminal pada Pertambangan Batubara yang Menyejahterakan Masyarakat Melalui Sarana Non-Penal}

Istilah "kebijakan"18 berasal dari bahasa asing "Policy" atau "beleid" atau "wijbeleid", dapat diartikan sebagai suatu keputusan yang menggariskan cara yang paling efektif dan paling efisien untuk mencapai suatu tujuan yang ditetapkan secara kolektif. Adapun oleh David L. Sills, kebijakan diartikan sebagai suatu perencanaan atau program mengenai apa yang akan dilakukan dalam menghadapi problem tertentu dan cara bagaimana melakukan atau melaksanakan sesuatu yang telah direncanakan

15 Amirudin "et.al", Pengantar Metode Penelitian Hukum, (Jakarta: Raja Grafindo Persada, 2000), hlm. 119.

16 Johnny Ibrahim, Teori dan Metodologi Penelitian Hukum Normatif, (Malang: Bayu Media Publising, Malang, 2006), hlm 302-303.

${ }^{17} \mathrm{Ibid}, \mathrm{hlm} .306$.

${ }^{18}$ Menurut Sutan Zanti Arbi dan Wayan Ardhana, istilah kebijakan terjemahan dari kata "Policy" sebagaimana dalam bukunya yang berjudul : "Rancangan Penelitian Kebijakan Sosial" diterbitkan oleh Pustekkom Dikbud dan CV. Rajawali tahun 1984. Istilah tersebut merupakan terjemahan dari "The Design of Social Policy", yang ditulis Robert R. Mayer dan Ernest Greenwood. 
atau diprogramkan. ${ }^{19}$ Beberapa penulis lain, seperti Muhadjirin Darwin dan Solichin Abdul Wahab, menggunakan istilah "Kebijakan sebagai terjemahan kata "Policy". Walaupun dalam tulisan yang lain Solichin menggunakan istilah Kebijaksanaan untuk menerjemahkan istilah "Policy". ${ }^{20}$

Kebijakan hukum pidana atau politik hukum pidana, dilihat dari politik hukum maupun politik kriminal dapat diartikan sebagai berikut:

a. usaha untuk mewujudkan peraturan-peraturan yang baik sesuai dengan keadaan dan situasi pada suatu saat; ${ }^{21}$

b. kebijakan dari negara melalui badan-badan yang berwenang untuk menetapkan peraturan-peraturan yang dikehendaki yang diperkirakan bisa digunakan untuk mengekspresikan apa yang terkandung dalam masyarakat dan untuk mencapai apa yang dicita-citakan. ${ }^{22}$

Pencegahan dan penanggulangan kejahatan dengan memanfaatkan sarana "penal" merupakan "penal policy" atau "penal law enforcement policy" yang terwujud lewat seperangkat norma-norma yang berlaku di masyarakat. Perangkat norma hukum tersebut dapat diklasifikasikan menjadi norma-norma hukum yang sedang berlaku (hukum positif/ius constitutum) dan norma-norma hukum pidana yang dicita-citakan (ius constituendum). Terkait dengan cara bagaimana merumuskan hukum pidana yang sebaiknya atau seharusnya untuk masa yang akan datang, berarti memasuki bidang ilmu tentang kebijakan atau politik hukum pidana (Strafrechtpolitiek/ criminal-law policy/penal-policy).

Menurut Marc Ancel, Penal Policy merupakan salah satu komponen esensial dari "Modern Criminal Science" di samping "Criminology" dan "Criminal Law". ${ }^{23}$ Dikemukakan pula bahwa "Penal policy" adalah suatu ilmu sekaligus seni yang pada akhirnya memunyai tujuan praktis untuk memungkinkan peraturan hukum positif dirumuskan secara lebih baik dan untuk memberikan pedoman tidak hanya kepada pembuat undang-undang, tetapi juga kepada pengadilan yang menerapkan undang-undang dan juga kepada para penyelenggara atau pelaksana putusan pengadilan. ${ }^{24}$

Usaha dan kebijakan untuk membuat peraturan hukum yang lebih baik pada hakikatnya tidak dapat dilepaskan dari tujuan penanggulangan kejahatan. Kebijakan hukum pidana juga merupakan bagian dari politik atau

\footnotetext{
${ }^{19}$ Barda Nawawi Arief, Kebijakan Legislatif dalam Penanggulangan Kejahatandengan Pidana Penjara, (Semarang: Badan Penerbit Universitas Diponegoro, 1994), hlm. 63.

${ }^{20}$ Dwidja Priyatno, Kebijakan Legislasi tentang Sistem Pertanggungjawaban Pidana Korporasi di Indonesia, (Bandung: Utomo, 2004), hlm.139.

${ }^{21}$ Sudarto. Kapita Selekta Hukum Pidana, (Bandung: Alumni, 1981), hlm. 159.

${ }^{22}$ Sudarto.Hukum Hukum Pidana dan Perkembangan Masyarakat, Kajian terhadap Pembaharuan Hukum Pidana, (Bandung: Sinar Baru, 1983), hlm. 20.

${ }^{23}$ Marc Ancel, Social Defance, A Modern Approach to Criminal Problems (London: Routlarge \& Kegan Paul, 1965), hlm. 4-5.

${ }^{24}$ Barda Nawawi Arief, Tanpa Tahun., Op.Cit., hlm. 1.
} 
kebijakan kriminal (criminal policy). Sudarto mengungkapkan bahwa kebijakan kriminal dapat diuraikan kedalam tiga arti, yaitu :

a. dalam arti sempit, adalah sebagai keseluruhan asas dan metode yang menjadi dasar dari reaksi terhadap pelanggaran hukum yang berupa pidana;

b. dalam arti luas, adalah keseluruhan fungsi dari aparatur penegak hukum, termasuk didalamnya cara kerja dari pengadilan dan polisi; dan

c. dalam arti paling luas, adalah keseluruhan kebijakan yang dilakukan melalui perundang-undangan dan badan resmi, yang bertujuan untuk menegakkan norma-norma sentral dalam masyarakat. ${ }^{25}$

Sebagaimana telah diuraikan bahwa kebijakan atau upaya penanggulangan masalah kejahatan pada hakikatnya merupakan bagian integral dari upaya perlindungan masyarakat (social defence) untuk mencapai kesejahteraan sosial (social walfare). Oleh karena itu, dapat dikatakan bahwa tujuan akhir dari kebijakan kriminal ialah "perlindungan masyarakat" untuk mencapai tujuan utama yang sering disebut dengan berbagai istilah, seperti "kebahagiaan warga masyarakat/penduduk" (happiness of the citizen); "kehidupan kultural yang sehat dan menyegarkan" (a wholesome and cultural living); "kesejahteraan masyarakat" (social welfare) atau untuk mencapai "keseimbangan" (equality). ${ }^{26}$

Pencegahan dan penanggulangan kejahatan haruslah menunjang tujuan tercapainya perlindungan terhadap masyarakat (social defence), sehingga terciptanya kesejahteraan masyarakat (social welfare). Dari kedua aspek tersebut, yang sangat penting adalah tercapainya aspek perlindungan serta aspek kesejahteraan yang bersifat immaterial, terutama nilai-nilai kepercayaan, kejujuran serta keadilan. Dengan demikian, pencegahan serta penanggulangan terhadap masalah kejahatan harus dilakukan dengan pendekatan yang komprehensif dan integral serta adanya keseimbangan antara pendekatan penal dan non-penal.

Barda Nawawi Arief, mengungkapkan bahwa ada dua masalah sentral dalam kebijakan kriminal dengan menggunakan sarana penal/hukum pidana, yaitu:

a. masalah penentuan perbuatan apa yang seharusnya dijadikan sebagai tindak pidana; dan

b. sanksi apa yang sebaiknya digunakan atau dikenakan kepada si pelanggar.

Kedua masalah sentral tersebut tidak dapat dilepaskan dari konsepsi integral antara kebijakan kriminal dengan kebijakan sosial atau kebijakan

${ }^{25}$ Op.Cit., Sudarto, Kapita Selekta ..., hlm. 113-114, lihat juga Hukum dan Hukum Pidana, 1981, hlm. 161.

${ }^{26}$ Muladi dan Barda Nawawi Arief, Teori-Teori dan Kebijakan Pidana, (Bandung: Alumni, 1984), hlm. 158. 
pembangunan nasional. Artinya, pemecahan kedua masalah tersebut harus pula diarahkan untuk mencapai tujuan-tujuan tertentu dari kebijakan sosial politik yang telah ditetapkan. Dengan demikian, kebijakan hukum pidana, termasuk menangani masalah sentral di atas, harus pula dilakukan dengan pendekatan yang berorientasi pada kebijakan. Sudah barang tentu pendekatan kebijakan yang integral ini tidak hanya dalam bidang hukum pidana tetapi juga pada pembangunan hukum pada umumnya. ${ }^{27}$

Berkaitan dengan masalah sentral kebijakan kriminal tentang penentuan tindak pidana, agar tujuan yang hendak dicapai sesuai dengan yang diharapkan, maka hal yang sangat penting untuk diperhatikan adalah sifat dan hakikat dari perbuatan jahat tersebut. Erat kaitannya dengan persoalan perbuatan yang dapat dikategorikan suatu tindak pidana atau seringkali disebut dengan kriminalisasi, menurut Sudarto perlu diperhatikan hal-hal yang pada intinya, sebagai berikut: ${ }^{28}$

a. penggunaan hukum pidana harus memerhatikan tujuan pembangunan nasional yaitu mewujudkan masyarakat adil makmur yang merata materiil dan spirituil berdasarkan Pancasila; sehubungan dengan ini maka penggunaan hukum pidana bertujuan untuk menanggulangi kejahatan dan mengadakan pengugeran terhadap tindakan penanggulangan itu sendiri, demi kesejahteraan dan pengayoman masyarakat;

b. perbuatan yang diusahakan untuk dicegah atau ditanggulangi dengan hukum pidana harus merupakan perbuatan yang tidak dikehendaki, yaitu perbuatan yang mendatangkan kerugian baik materiil maupun spirituil atas warga masyarakat;

c. penggunaan hukum pidana harus pula memperhitungkan prinsip "biaya dan hasil" (cost and benefit principle); dan

d. penggunan hukum pidana harus pula memperhatikan kapasitas atau kemampuan daya kerja dari badan-badan penegak hukum, yaitu jangan sampai ada kelampauan beban tugas (overbelasting).

Atas dasar hal itu, maka kebijakan kriminal terhadap masalah kejahatan harus benar-benar ditujukan untuk menanggulangi perilaku menyimpang serta menentukan norma-norma terhadap tindakan-tindakan penanggulangan demi kesejahteraan dan pengayoman pelaku tindak pidana.

Menyangkut masalah sentral yang kedua, sanksi apakah yang sebaiknya dikenakan terhadap pelaku kejahatan. Para ahli mengungkapkan bahwa hendaknya sanksi yang dijatuhkan benar-benar dapat sejalan dengan konsepsi perlindungan masyarakat (social defence). Hasil maksimum harus dicapai dengan biaya yang minimum bagi masyarakat, dan minimum

\footnotetext{
${ }^{27}$ Barda Nawawi, Bunga Rampai Kebijakan Hukum Pidana, (Bandung: Citra Aditya Bakti, 1996), hlm. 32-33.

${ }^{28}$ Sudarto, Hukum dan Hukum Pidana, (Bandung: Alumni, 1986), hlm. 36-40.
} 
penderitaan bagi individu. Menurut Ted Honderich sebagaimana dikutip Barda Nawawi ${ }^{29}$, menyatakan bahwa pidana dapat disebut alat pencegah yang ekonomis, apabila dipenuhi syarat-syarat, sebagai berikut:

a. pidana itu sungguh-sungguh mencegah;

b. pidana itu tidak menyebabkan timbulnya keadaan yang lebih berbahaya atau merugikan daripada yang akan terjadi apabila pidana itu tidak dikenakan;

c. tidak ada pidana lain yang dapat mencegah secara efektif dengan bahaya atau kerugian yang lebih kecil.

Adapun menurut Bassiouni, bahwa pidana hendaknya dapat mewujudkan tujuan-tujuan dalam upaya memenuhi perlindungan kepentingan sosial, antara lain:

a. memelihara tertib masyarakat;

b. melindungi warga masyarakat dari kejahatan, kerugian atau bahayabahaya yang tidak dapat dibenarkan, yang dilakukan oleh orang lain;

c. memasyarakatkan kembali para pelanggar hukum; dan

d. memelihara atau mempertahankan integritas pandangan-pandangan dasar tertentu mengenai keadilan sosial, martabat kemanusiaan dan keadilan individu.

Pidana hanya dibenarkan apabila ada suatu kebutuhan yang berguna bagi masyarakat; suatu pidana yang tidak diperlukan, tidak dapat dibenarkan dan berbahaya bagi masyarakat. ${ }^{30}$

Dari uraian diatas penerapan sarana hukum pidana atau penal harus bertujuan mencapai kesejanteraan masyarakat dan perlindungan masyarakat. Kebijakan kriminalisasi merupakan suatu kebijakan dalam menetapkan suatu perbuatan yang semula bukan suatu tindak pidana menjadi perbuatan pidana. Pada hakekatnya, kebijakan kriminalisasi merupakan bagian dari kebijakan kriminal (criminal policy) dengan menggunakan sarana hukum pidana dan oleh karena itu termasuk bagian dari kebijakan hukum pidana (penal policy). ${ }^{31}$

Kebijakan hukum pidana dalam Undang-Undang Nomor 4 Tahun 2009 tentang Pertambangan Mineral Batubara yaitu Pasal 162 yang menyebutkan bahwa setiap orang yang merintangi atau mengganggu kegiatan usaha pertambangan dari pemegang IUP atau IUPK yang telah memenuhi syarat-syarat sebagaimana dimaksud Pasal 136 ayat (2) $)^{32}$ dipidana dengan pidana kurungan paling lama 1 tahun atau denda paling banyak IDR 100.000.000 (seratus juta rupiah). Walaupun Pasal 162 jo Pasal 136 ayat (2)

\footnotetext{
${ }^{29}$ Op.Cit., Ted Honderich dalam Muladi dan Barda Nawawi Arief, hlm.165.

${ }^{30}$ Muladi dan Barda Nawawi Arief. Idem, hlm. 165.

${ }^{31}$ Barda Nawawi Arief, Bunga Rampai Kebijakan Hukum Pidana, (Bandung: Citra Aditya Bakti, 2002), hlm. 2-3.

${ }^{32}$ Penyelesain hak atas tanah sesuai dengan kebutuhan pemegang IUP atau IUPK.
} 
Undang-Undang Nomor 4 Tahun 2009 tentang Pertambangan Mineral dan Batubara, pernah dimohonkan untuk diuji materil akan tetapi permohonan tersebut ditolak oleh mahkamah konstitusi. Mahkamah kontitusi beranggapan bahwa permohonan tersebut tidak terbukti menurut hukum, dengan putusan mahkamah konstitusi yang menolak permohonan tersebut maka Pasal 162 jo Pasal 136 (2) Undang-Undang Nomor 4 Tahun 2009 tentang Pertambangan Mineral dan Batubara masih berlaku, sehingga setiap orang yang merintangi kegiatan usaha pertambangan bisa dipidana.

Bentuk perintangan pertambangan batubara bisa bermacam-macam tidak hanya berkaitan dengan orang yang memunyai hak atas tanah, akan tetapi penduduk sekitar juga terkena dampak langsung atau tidak langsung. Walaupun perusahaan diberikan kewajiban untuk reklamasi dan melaksanakan perbaikan lingkungan pasca tambang serta melaksanakan kegiatan pemberdayaan masyarakat, akan tetapi ketika kegiatan tersebut kurang dirasakan oleh masyarakat maka masyarakat biasa melakukan penyampaian pendapat melalui tindakan-tindakan yang mungkin saja dianggap merintangi kegiatan pertambangan batubara sehingga masyarakat tersebut dipidanakan. Konsep kebjikan hukum pidana tersebut sangat jauh sekali dengan konsep-konsep hukum pidana, di mana hukum pidana tersebut menghendaki kesejahteraan masyarakat dan pengayoman bagi masyarakat.

Apabila penyelesaian dengan menggunakan hukum positif (sarana penal) tidak memberikan hasil yang memuaskan, maka penyelesaian sosiologis (sarana non-penal) bisa menjadi alternatif yang dapat memberikan rasa keadilan bagi masyarakat. Hukum negara bukan satu-satunya aturan yang memonopoli orang. Justru hukum rakyat atau hukum sosiologis dalam banyak konteks memperlihatkan efektifitas sebagai acuan berperilaku dan pengendalian sosial dalam masyarakat, termasuk didalamnya ketika terjadi konflik sosial dalam masyarakat.

Konflik antara perusahaan dan masyarakat tidak bisa diselesaikan dengan sarana penal, akan tetapi harus dicoba dengan sarana-sarana nonpenal. Dalam mengatasi konflik-konflik sejak dini perusahaan-perusahaan yang mau beroperasi perlu membentuk struktur organisasi masyarakat agar masyarakat bisa berpartisipasi dalam memperjuangkan hak-haknya. Bentuk pengakuan perusahaan terhadap masyarakat adalah masyarakat diberi kesempatan untuk berpartisipasi dalam mengawasi kegiatan usaha pertambangan batubara dan difasilitasi untuk membentuk organisasi agar posisi tawar masyarakat dengan perusahaan menjadi seimbang. Selain itu adanya partisipasi tersebut adalah sarana untuk mendengar pendapat atau keluhan dari masyarakat, sehingga masyarakat tidak akan melakukan tindakan-tindakan yang akan merintangi pertambangan. Partisipasi adalah kemampuan masyarakat untuk memengaruhi kegiatan-kegiatan perusahaan sehingga dapat meningkatkan kesejahteraannya. 
Terkait partisipasi masyarakat maka untuk memperkuat partisipasi masyarakat adalah dengan cara demokrasi Deliberatif. Demokrasi deliberatif adalah upaya membangun mekanisme yang memungkinkan masyarakat untuk berpartisipasi dalam proses pembentukan, sehingga mereka dapat menjadi bagian dari perbuatan rencana secara aktual dan mengembangkan proposal. Istilah deliberation berarti konsultasi "menimbang-nimbang" atau musyawarah. Teori demokrasi deliberatif tidak memusatkan diri pada penyusunan daftar aturan-aturan tertentu yang menunjukkan apa yang harus dilakukan warga negara, melainkan pada prosedur untuk menghasilkan aturan-aturan itu. ${ }^{33}$ Bentuk-bentuk partisipasi masyarakat dari yang tertinggi sampai yang terendah: ${ }^{34}$

\begin{tabular}{|l|l|l|}
\hline Tinggi & $\begin{array}{l}\text { Memiliki } \\
\text { kontrol }\end{array}$ & $\begin{array}{l}\text { Organisasi meminta masyarakat } \\
\text { mengidentifikasi masalah dan membuat } \\
\text { seluruh keputusan kunci tentang tujuan dan } \\
\text { cara-cara. Bersedia membantu masyarakat } \\
\text { pada setiap langkah untuk menyelesaikan } \\
\text { tujuan. }\end{array}$ \\
\hline Mendelegasikan & $\begin{array}{l}\text { Organisasi mengidentifikasi dan } \\
\text { mempresentasikan sebuah masalah kepada } \\
\text { masyarakat, menetapkan batas-batas } \\
\text { meminta masyarakat membuat serangkaian } \\
\text { keputusan yang dapat dimasukkan ke dalam } \\
\text { sebuah rencana yang akan diterimanya. }\end{array}$ \\
\hline Merencanakan & $\begin{array}{l}\text { Organisasi mempresentasikan sebuah } \\
\text { rencana sementara yang dapat berubah dan } \\
\text { terbuka untuk menerima masukan dari } \\
\text { mereka yang terkena pengaruh. Kemudian } \\
\text { mengharapkan dapat mengubah rencana } \\
\text { sedikit atau banyak. }\end{array}$ \\
\hline Menasehati & $\begin{array}{l}\text { Organisasi mempresentasikan sebuah } \\
\text { rencana dan mengundang pertanyaan- } \\
\text { pertanyaan. Bersiap mengubah rencana } \\
\text { hanya sangat diperlukan. }\end{array}$ \\
\hline Dikonsultasikan & $\begin{array}{l}\text { Organisasi mencoba mempromosikan } \\
\text { sebuah rencana. Berupaya mengembangkan }\end{array}$ \\
\hline
\end{tabular}

${ }^{33}$ F. Budi Hardiman, Demokrasi Deliberatif Menimbang Negara Hukum dan Ruang Publik dalam Teori Diskursus Jurgen Hubermas, (Yogyakarta: Kanisius, 2009), hlm. 128.

${ }^{34} \mathrm{Jim}$ Ife dan Frank Manullang, Community Development:community-Based in on Age of Globalitation, diterjemahkan oleh Sastrawan Manullang, dkk, Community Development: Alternatif Pengembangan Masyarakat di Era Globalisasi, cet 1, (Yogyakarta: Pustaka Pelajar, 2008), hlm. 301. 


\begin{tabular}{|l|l|l|}
\hline & & $\begin{array}{l}\text { dukungan untuk mempermudah penerimaan } \\
\text { atau memberikan sanksi secukupnya } \\
\text { kepada rencana sehingga persetujuan } \\
\text { administratif dapat diharapkan }\end{array}$ \\
\hline & $\begin{array}{l}\text { Menerima } \\
\text { informasi }\end{array}$ & $\begin{array}{l}\text { Organisasi membuat sebuah rencana dan } \\
\text { mengumumkannya. Masyarakat dipanggil } \\
\text { rapat untuk maksud pemberian informasi. } \\
\text { Persetujuan diharapkan }\end{array}$ \\
\hline Rendah & Nihil & Masyarakat tidak diberitahu apa-apa \\
\hline
\end{tabular}

Dalam masyarakat modern telah terjadi saling perubahan fundamental yang oleh Hegel disebut tatanan sosial-moral. Istilah ini mengacu pada sebuah kenyataan bahwa di dalam masyarakat tradisional hukum dan moral saling berkelindan di dalam cara hidup partikular sebuah komunitas, sehingga moral itu sosial dan tatanan sosial itu bercirikan moral sekaligus legal. Hukum dan moral modern memiliki asal usul yang sama yaitu, tatanan sosial moral tradisional. Modernisasi telah menghempaskan hukum sebagai suatu wilayah otonom dari moral sehingga masyarakat modern hukum dan moral di pandang dua bidang yang berbeda atau bahkan kerap terpisah. ${ }^{35}$

Pemisahan hukum dan moral berpengaruh terhadap cara berhukum suatu bangsa dan penerapan kebijakan kriminal suatu bangsa. Dalam konteks Pasal 162 Undang-Undang Nomor 4 Tahun 2009 tentang Pertambangan mineral dan Batubara di mana ada pertentangan antara hukum dan moral dalam menentukan suatu perbuatan menjadi suatu perbuatan yang tercela. Perbuatan tersebut harus dicegah dan ditanggulangi, penanggulangan tersebut diarahkan pada sarana non-penal. Sarana non-penal dilakukan dengan membuat organisasi di mana didalamnya ada tindakan komunikatif yang menghasilkan solidaritas sosial secara efektif. Lewat tindakan komunikatif dengan cara demokrasi deliberatif maka perusahaan dan masyarakat saling berkomunikasi yang pada akhirnya hasil dari komunikasi tersebut adalah sebagai patokan bagi perusahaan dalam menjalankan perusahaan. Ketika kesepakatan perusahaan dengan masyarakat tercapai maka perusahaan menjalankan bisnisnya akan lebih tentram dan damai, karena telah mendapat legitimasi dari masyarakat.

Cara pelaksanaan partisipasi bisa dilakukan pada saat pra tambang ataupun pada saat tambang itu sedang berjalan. Pada saat pra tambang bisa dilakukan dengan Free, Prior and Informed Consent (FPIC). FPIC sebuah konsep mencoba mensinergiskan kebutuhan dan keberlangsungan investasi dengan proses memakmurkan masyarakat setempat. FPIC adalah perundingan-perundingan tanpa paksaan antara investor dan perusahaan atau

\footnotetext{
${ }^{35}$ Op. Cit., F. Budi Hardiman, hlm. 57.
} 
antara pemerintah dan masyarakat sebelum perusahaan melakukan pertambangan di wilayah mereka. FPIC secara sederhana merupakan sebuah hak untuk memutuskan jenis kegiatan pembangunan apa yang diperbolehkan untuk berlangsung dalam wilayah mereka. Prinsip tersebut juga mengandung makna kebebasan masyarakat ya atau tidak kepada proyek pembangunan yang direncanakan akan dilaksanakan dalam wilayah mereka. ${ }^{36}$

Undang-Undang Nomor 4 Tahun 2009 tentang pertambangan mineral dan batubara dalam Pasal 162 menyebutkan bahwa setiap orang yang merintangi atau mengganggu kegiatan usaha pertambangan dari pemegang izin usaha pertambangan dan izin usaha pertambangan khusus dikenakan sanksi denda atau hukuman penjara. Pasal ini memperlihatkan bahwa partisipasi masyarakat dalam menyatakan pendapat atau bentuk pengawasan terhadap perusahaan dihambat, seharusnya peraturan tersebut lebih mengakomodir hak-hak masyarakat untuk memerjuangkan hidupnya. Terkait pembahasan partisipasi, berikut ini disajikan bagan yang menerangkan tentang proses informasi dampak:

\section{Bagan 1. \\ Proses Informasi Dampak Kegiatan Pertambangan}

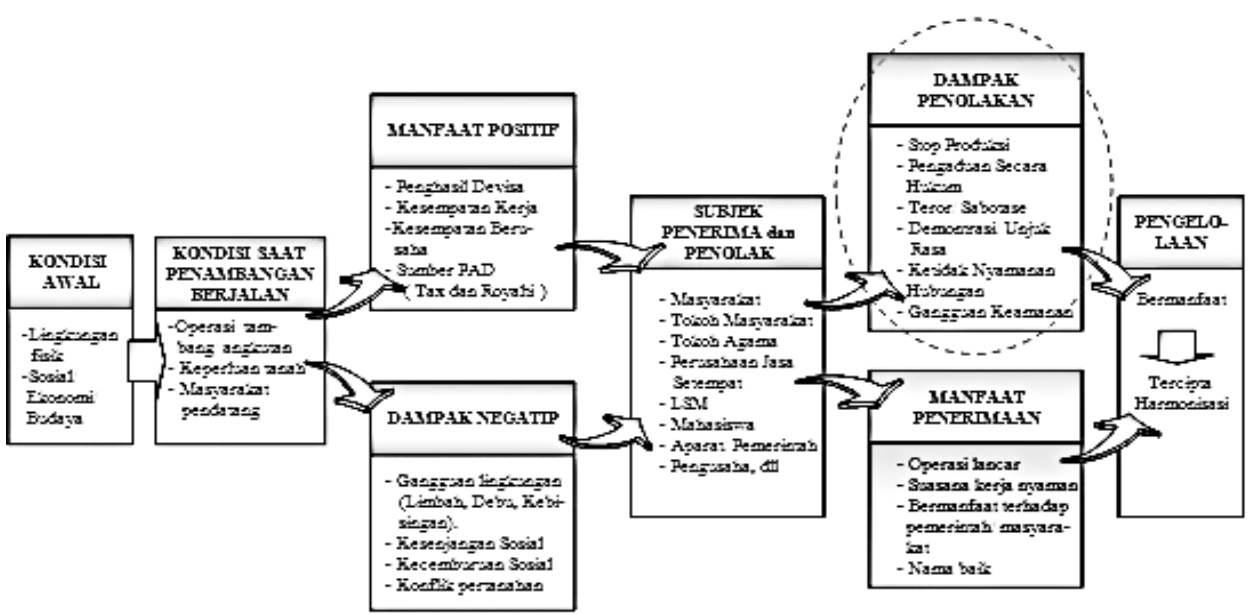

(sumber: PT. Kalimantan Prima Persada)

Seperti digambarkan di atas, perusahaan harus mengidentifikasi kondisi-kondisi lingkungan yang akan dijadikan area pertambangan yaitu lingkungan fisik, sosial ekonomi dan budaya. Selanjutnya, perusahaan harus memberikan pengetahuan atau informasi kepada masyarakat tentang kondisi-

36 Lokakarya tentang Free, Prior and Informed Consent' membuat FPIC bekerja bagi masyarakat dan perusahaan, Pekanbaru 26-28 November 2007. 
kondisi pada saat pertambangan berjalan baik kondisi yang bermanfaat atau kondisi-kondisi yang bisa membahayakan mereka. Setelah perusahaan memberikan informasi tentang kondisi-kondisi pada saat kegiatan pertambangan, masyarakat bisa menentukan apakah kegiatan pertambangan tersebut akan diterima atau ditolak. Dengan dilakukan pendekatan dengan memberikan informasi terlebih dahulu maka perusahaan akan lebih aman mengelola kegiatan pertambangan demi tercapainya peningkatan kesejahteraan masyarakat.

Selain pada saat pra tambang, kegiatan partisipasi tersebut juga dilakukan pada saat perusahaan itu beroperasi. Kegiatan partisipasi tersebut dilakukan melalui organisasi yang ada di masyarakat yang anggotanya tidak hanya dari masyarakat tetapi perusahaan ikut berada dalam organisasi tersebut. Organisasi ini bertujuan untuk penyampaian keluhan-keluhan terhadap perusahaan dan sebagai upaya untuk memediasi keinginankeinginan masyarakat supaya tidak terjadi konflik berkepanjangan. Digunakannya mediasi dalam menyelesaikan perselisihan perusahaan dan masyarakat karena mediasi memandang suatu penyelesaian masalah ke depan, bukan ke masa lampau. Hukum memandang ke belakang untuk menemukan siapa yang benar dan siapa yang salah; mediasi memandang ke depan untuk menemukan solusi di mana para pihak bisa menyesuaikan diri. Di dalam hukum, pengadilan menggunakan kekuasaaannya untuk memerintahkan suatu putusan, sedangkan dalam mediasi, anda memberikan kewenangan pada diri anda sendiri untuk menemukan solusi anda sendiri. ${ }^{37}$ Jadi mediasi lebih mengakomodir kehedak para pihak, sehingga para pihak tidak dirugikan.

\section{Penutup}

\section{Simpulan}

Kebijakan kriminal memunyai tujuan untuk perlindungan terhadap masyarakat, sehingga terciptanya kesejahteraan masyarakat. Kebijakan kriminal dalam Pasal 162 Undang-Undang Nomor 4 Tahun 2009 tentang Pertambangan Mineral dan Batubara tidak memberikan perlindungan dan kesejahteraan bagi masyarakat. Untuk itu, maka kebijakan kriminal yang menggunakan sarana penal harus bergeser kepada sarana non-penal. Penerapan sarana non-penal dilakukan dengan membentuk organisasi di mana dalamnya melakukan tindakan-tindakan komunikatif dengan cara demokrasi deliberatif. Demokrasi deliberatif sebagai sarana untuk memfasilitasi masyarakat untuk berpartisipasi dalam organisasi tersebut. Partisipasi tersebut dilakukan pada pra pertambangan dilakukan untuk

\footnotetext{
${ }^{37}$ Ahmad Ali dan Wiwie Heryani, Sosiologi Hukum Kajian Empiris Terhadap Pengadilan,
} Cet 1, (Jakarta: Kencana Prenada Media Grup, 2012), hlm. 26. 
mendapatkan legitimasi masyarakat dan pada saat pertambangan sedang beroperasi dilakukan untuk memediasi konflik-konfilik akibat beroperasinya pertambangan.

\section{Saran}

Pemerintah harus mengaji atau membatalkan Pasal 162 UndangUndang Nomor 4 Tahun 2009 tentang Pertambangan Mineral Batubara yang menghukum setiap orang yang merintangi kegiatan pertambangan, dengan Pasal ini masyarakat dirampas hak-haknya untuk menyuarakan keberatan tentang keberadaan perusahaan pertambangan.

\section{Daftar Pustaka}

\section{A. Buku}

Ali, Ahmad dan Heryani, Wiwie, 2012, Sosiologi Hukum Kajian Empiris Terhadap Pengadilan, Cet 1, Jakarta: Kencana Prenada Media Grup.

Ancel, Marc, 1965, Social Defance, A Modern Approach to Criminal Problems, London: Routlarge \& Kegan Paul.

Arief, Barda Nawawi, 2002, Bunga Rampai Kebijakan Hukum Pidana, Bandung: Citra Aditya Bakti.

, 1994, Kebijakan Legislatif dalam Penanggulangan

Kejahatandengan Pidana Penjara, Semarang: Badan Penerbit Universitas Diponegoro.

Hatta, Mohammad, 1967, Ekonomi Terpimpin, Jakarta: Djambatan.

Muladi dan Arief, Barda Nawawi, 1984, Teori-Teori dan Kebijakan Pidana, Bandung: Alumni.

Priyatno, Dwidja, 2004, Kebijakan Legislasi tentang Sistem Pertanggungjawaban Pidana Korporasi di Indonesia, Bandung: Utomo.

Saleng, H. Abrar, 2004, Hukum Pertambangan, Cet 2, Yogyakarta: UII Press.

Sudarto, 1986, Hukum dan Hukum Pidana, Bandung: Alumni. , 1983, Hukum Hukum Pidana dan Perkembangan Masyarakat, Kajian terhadap Pembaharuan Hukum Pidana, Bandung: Sinar Baru. 1981, Kapita Selekta Hukum Pidana, Bandung: Alumni.

Sutendi, Andrian, 2011, Hukum Pertambangan, Cet 1, Jakarta: Sinar Garfika.

\section{B. Peraturan Perundang-Undangan}


Undang-Undang Nomor 4 Tahun 2009 tentang Pertambangan Mineral dan Batubara

\section{Sumber lain}

Hukumonline, unsur pemidanaan di UU minerba, diakses tanggal Februari 2013

Kamus Besar Bahasa Indonesia (edisi kedua), 1995, Jakarta: Departemen Pendidikan dan Kebudayaan \& Balai Pustaka.

Pan Mohamad Faiz, Penafsiran Konsep Penguasaan Negara Berdasarkan Pasal 33 UUD 1945 dan Putusan Mahkamah Konstitusi, www. Jurnal Hukum. Blogspot.com, diakses 24 November 2010. 